\title{
Ureteric carcinoma
}

\author{
Stephen A. Gellera ${ }^{a}$ Fernando P. F. de Campos $^{b}$
}

Geller SA, Campos FPF. Ureteric carcinoma. Autopsy Case Rep [Internet]. 2014; 4(1): 63-64. http://dx.doi.org/10.4322/ acr.2014.010

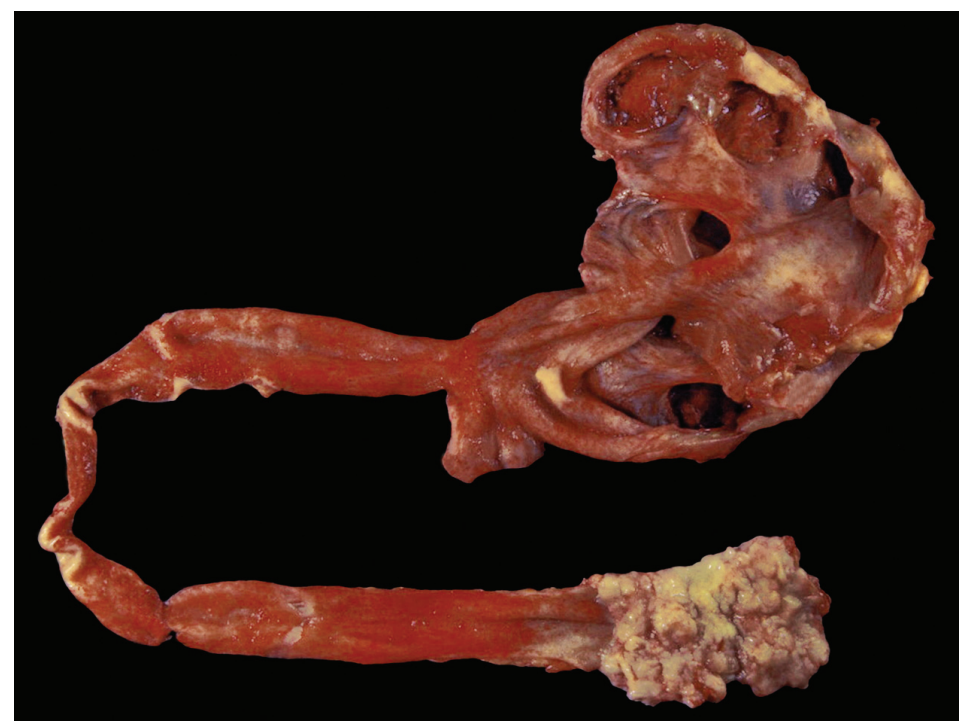

Picture provided by Dr. Stephen A. Geller - personal archive.

Ureteric neoplasms are rare tumors. The annual incidence (during the period 1995-2005) was $0,95-1,15 / 100.000$ person-year. They are almost always urothelial tumors, especially papillary transitional cell carcinoma, as in the image above, and are less common than tumors of the renal pelvis and 10 times less common than urinary bladder tumors. In a large series of 1249 cases of urothelial neoplasms of the upper urinary tract (pelvis and ureter) (upper urinary tract tumors; UUTT) $34 \%$ of the cases involved the ureter, and in $8 \%$ the neoplasia was found in both sites concomitantly. Concomitance with bladder tumors is also observed, either synchronously or methachronously. When metachronous; bladder tumors precede UUTT in $10,2 \%$ of cases, and when synchronous in $49 \%$. Both ureters are equally involved and involvement of both ureters was found in 15 out of 930 cases. Although the distal ureter is the most common location of ureteral tumors, and multifocal implants may also occur, tumor location should not be used to predict outcomes neither clinical decisions. Ureteral neoplasms are more likely to present with organ-confined disease, possibly because small UUTT can cause early symptoms. When these tumors metastasize they usually spread to lymph nodes, lungs, liver, bone and brain. UUTT are more common in males (M:F = 2:1). In the USA, it is estimated that 3000 new cases occur per year with the numbers increasing slowly each year. The median age at diagnosis is 71 years, and highergrade tumors are most likely to occur in the elderly. Environmental factors have been implicated. In 2013, Holmäng et al published a retrospective study of 930 UUTT cases and found a relationship to previous abdominal radiotherapy in $16,7 \%$ of cases generally with a latency period of at least 15 years. Phenacetin-containing analgesics is known to be

\footnotetext{
a Department of Pathology and Laboratory Medicine - Weill Medical College of Cornell University, New York/NY - EUA.

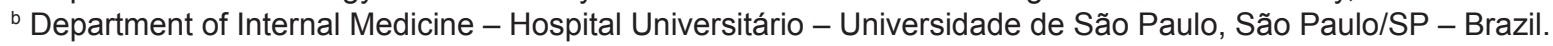

Copyright $\odot 2014$ Autopsy and Case Reports - This is an Open Access article distributed of terms of the Creative Commons Attribution NonCommercial License (http://creativecommons.org/licenses/by-nc/3.0/) which permits unrestricted non-commercial use, distribution, and reproduction in any medium provided article is properly cited.
} 
related to UUTT; Steffens and Nagel showed $22 \%$ of these tumors associated with analgesic abusers. In Taiwan, arsenic exposure was associated with the development of upper urinary tract cancer. Chinese herbs containing aristolochic acid may cause progressive renal fibroses and is also associated with significant increase in the incidence of urothelial tumors of renal pelvis or ureter. Other contributory factors include Balkan endemic nephropathy and Lynch syndrome. It is noteworthy that, in contrast to bladder cancer, cigarette smoking was not related to ureteric neoplasms.

Over $90 \%$ of the UUTT are of urothelial origin (transitional cells) with almost $8 \%$ being squamous cell carcinoma The tumor growth pattern may be solid, papillary or mixed; the former presents a poor prognosis. Metastatic tumors can also affect the ureters.

Clinically, the most frequent sign is hematuria occurring in $75 \%$ - $90 \%$ of cases, followed by symptoms of obstruction mostly represented by flank pain ( $8 \%-40 \%$ of cases), bladder irritation and constitutional symptoms. The image also shows advanced hydroureter and hydronephrosis with marked renal parenchymal atrophy. Some patients are asymptomatic, with diagnosis established after screening urinalysis demonstrates microhematuria or when abdominal ultrasonography is performed for an unrelated reason. Physical examination is routinely unrevealing. Cytologioc studies of the urine can be difficult to interpret because of degeneration of tumor cells in the urine but imaging studies generally demonstrate the tumor as well as the hydronephrosis.

Keywords: Ureteral Neoplasms; Hydronephrosis.

\section{BIBLIOGRAPHY}

1. Geller SA, Lin C-S. Ureteral obstruction from metastatic breast carcinoma. Arch Path. 1975;100:476-8.

2. Holmäng S, Holmberg E, Johansson SL. A population-based study of tumours of the renal pelvis and ureter: Incidence, aetiology and histopathological findings. Scand J Urol. 2013;47:491-6. http://dx.doi.org/10.3109/21681805.2013 .795188

3. Holmäng S, Johansson SL. Urothelial carcinoma of the upper urinary tract: comparison between the WHO/ISUP 1998 consensus classification and WHO 1999 classification system. Urology. 2005;66:274-8. http://dx.doi.org/10.1016/j. urology.2005.03.011

4. Lynch HT, Ens JA, Lynch JF. The Lynch syndrome II and urological malignancies. J Urol. 1990;143:24.

5. McCredie M, Stewart JH, Ford JM. Analgesics and tobacco as risk factors for cancer of the ureter and renal pelvis. $J$ Urol. 1983;130:28-30.

6. Nortier JL, Martinez MC, Schmeiser HH, et al. Urothelial carcinoma associated with the use of a Chinese herb (Aristolochia fangchi). N Engl J Med. 2000; 342:1686-92. http://dx.doi.org/10.1056/NEJM200006083422301

7. Olgac S, Mazumdar M, Dalbagni G, Reuter VE. Urothelial carcinoma of the renal pelvis: a clinicopathologic study of 130 cases. Am J Surg Pathol. 2004;28:1545-52. http://dx.doi. org/10.1097/00000478-200412000-00001

8. Raman JD, Messer J, Sielatycki JA, Hollenbeak CS. Incidence and survival of patients with carcinoma of the ureter and renal pelvis in the USA, 1973-2005. BJU Int. 2011;107:1059-64. http://dx.doi.org/10.1111/j.1464-410X.2010.09675.x

9. Raman JD, Ng CK, Scherr DS, et al. Impact of tumor location on prognosis for patients with upper tract urothelial carcinoma managed by radical nephroureterectomy. Eur Urol. 2010;57:1072-9. http://dx.doi.org/10.1016/j. eururo.2009.07.002

10. Steffens J, Nagel R. Tumours of the renal pelvis and ureter. Br J Urol. 1988;61:277-83. http://dx.doi.org/10.1111/j.1464410X.1988.tb13957.x

11. Yang MH, Chen KK, Yen CC, et al. Unusually high incidence of upper urinary tract urothelial carcinoma in Taiwan. Urology. 2002;59:681. http://dx.doi.org/10.1016/S0090-4295(02)01529-7

\section{Stephen A. Geller, M.D.}

Department of Pathology and Laboratory Medicine

Weill Medical College of Cornell University

New York - USA

geller16st@gmail.com

\section{Fernando P. F. de Campos, PhD}

Department of Internal Medicine

Hospital Universitário - USP

São Paulo/SP - Brazil

fpfcampos@gmail.com 